FINANCIAL: Jurnal Akuntansi

Published by Program Studi Akuntansi STIE Sultan Agung

Volume 6-Nomor 1, Juni 2020, (HIm 87-97)

ISSN-P: 2502-4574, ISSN-E: 2686-2581

Available online at: https://financial.ac.id/index.php/financial

\title{
PENGARUH KUALITAS LAPORAN KEUANGAN TERHADAP AKUNTABILITAS KINERJA PADA BADAN PENGELOLAAN KEUANGAN DAN ASET DAERAH (BPKAD) KABUPATEN BUTON
}

\author{
Nining Asniar Ridzal \\ Program Studi Akuntansi, Universitas Muhammadiyah Buton, Baubau,Indonesia. \\ E-mail: niningasniarridzal84@gmail.com
}

\begin{abstract}
Abstrak
Tujuan penelitian ini adalah untuk mengetahui pengaruh kualitas laporan keuangan terhadap akuntabilitas kinerja pada Badan Pengelolaan Keuangan dan Aset Daerah Kabupaten Buton. Jenis penelitian adalah deskriptif. Data penelitian adalah data primer. Instrumen penelitian berupa kuisioner. Populasi penelitian adalah seluruh pegawai pada Badan Pengelolaan Keuangan dan Aset Daerah. Sampel penelitian berjumlah 35 orang. Teknik pengambilan sampel menggunakan non probability sampling dengan metode sensus. Data penelitian dianalisis menggunakan statistik inferensial dengan model regresi sederhana yang didahului oleh uji linearitas dan normalitas. Hasil analisis data menunjukkan bahwa nilai signifikansi yang diperoleh sebesar $0,000<\alpha$ sama dengan 0,05 maka dapat disimpulkan bahwa kualitas laporan keuangan berpengaruh positif dan signifikan terhadap akuntabilitas kinerja Badan Pengelolaan Keuangan dan Aset Daerah Kabupaten Buton. Hal ini berarti bahwa baik tidaknya akuntabilitas kinerja dari suatu instansi pemerintah sangat dipengaruhi oleh kualitas laporan keuangan yang dihasilkan. Jika akuntabilitas kinerja instansi pemerintah menyajikan laporan keuangan sesuai Standar Akuntansi pemerintahan maka laporan keuangan yang dihasilkan akan berkualitas.
\end{abstract}

Kata Kunci: Kualitas, Laporan Keuangan, Akuntabilitas, Kinerja

\section{THE EFFECT OF QUALITY OF FINANCIAL STATEMENTS ON ACCOUNTABILITY OF PERFORMANCE IN BADAN PENGELOLAAN KEUANGAN DAN ASET DAERAH (BPKAD) BUTON DISTRICT}

\begin{abstract}
This research aims to know the influence of financial statement quality to performance accountability in Badan Pengelolaan Keuangan dan Aset Daerah Kabupatan Buton. Type of research is descriptive. Data of research is primary data. Research instrument is questionnare. Population of this research is all the people on Badan Pengelolaan Keuangan dan Aset Daerah (BPKAD). Sample of this research is 35 people. The sampling technique use non probability sampling with sesnsus method. Research data was analyzed using inference statistik with a simple regression model that was preceded by a linearity and normality test. Results of data analysis show that the significance value is 0,000 below the a of 0,05, it can be concluded that financial statement quality give positive and significant influence to performance accountability at Badan Pengelolaan Keuangan dan Aset Daerah (BPKAD) Buton District. It show that good or no the performance accountability of government agency influenced of financial statement quality produced.
\end{abstract} Keywords: Quality, Financial Statements, Accountability, Performance

Article History: $\quad$ Received: 02 Mei 2020 Revised: 20 Mei 2020 Accepted: 29 Mei 2020 


\section{PENDAHULUAN}

Pelaksanaan kegiatan pelayanan publik yang mengacu pada UU No.32 tahun 2004 tentang Pemerintahan Daerah mengakibatkan dua keterkaitan strategis yaitu pertama, masyarakat daerah diberikan wewenang lebih besar untuk memilih arah, kebijakan, tujuan serta program hingga kegiatan oleh organisasi pemerintah dalam melayani masyarakat. kedua, pemerintah daerah diberikan kesempatan yang lebih besar untuk memperoleh, mengatur, dan mengalokasi dana yang diperlukan dalam urusan pelayanan kepada masyarakat mulai dari daerah hingga SKPD yang ada dibawahnya. (www.dpr.go.id, 2004)

Saat ini kinerja pemerintah daerah masih menjadi perhatian publik karena masyarakat belum merasakan dampak yang baik. Namun dengan terwujudnya konsep otonomi pemerintahan daerah, memberikan harapan baru kepada masyarakat agar pemerintahan mempunyai kinerja yang baik dalam penyusunan dan penyajian laporan keuangan (husaini, lucy aditya, 2013).

Standar Akuntansi Pemerintah (SAP) diatur oleh Peraturan Pemerintah (PP) Nomor 71 Tahun 2010 merupakan standar yang digunakan oleh pemerintah dalam menyusun laporan keuangan (Standar Akuntansi Pemerintah, 2010).

\section{Adanya Peraturan Pemerintah} mengenai penyusunan laporan keungan menjadi bahan acuan bagi pemerintah daerah guna menyusun dan mengahsilkan laporan keuangan yang berkualitas.

Pemerintahan sebagai organisasi yang melayani masyarakat, dalam pengelolaannya harus dilakukan secara transparan dan akuntabel. Saat ini salah satu hal yang dianggap penting adalah keikutsertaan dalam membentuk pemerintahan yang baik. Pengelolaan pemerintahan daerah yang akuntabel, tidak terlepas dari pengelolaan APBD, Pengelolaan pemerintah daearah yang berakuntabilits tidak lepas dari anggaran pemerintah daerah, dimana hal tersebut berhubungan dengan fungsi pemerintah daerah dalam memberikan pelayanan kepada masyarakat (Sakti \& Masitoh, 2018)

Komponen yang penting dalam menciptakan akuntabilitas atas lembagalembaga publik adalah dengan penyusunan laporan keuangan sektor publik.Pembuatan laporan keuangan yang tepat merupakan suatu bentuk kebutuhan transparansi yang merupakan syarat pendukung adanya akuntabiltas berupa keterbukaan pemerintah akibat aktivitas pengelolaan sumber daya publik (S.C. Darwanis, 2013).Oleh karena itu, kewajiban dari instansi pemerintah adalah mengelolakeuangan serta mempertanggung jawabkan penggunaan keuangannya sesuai dengan tugas pokok dan fungsinya berdasarkan perencanaan strategis yang telah ditetapkan karena laporan keuangan yang transparan dan akuntabel merupakan wujud pengelolaan keuangan daerah yang dapat dipertanggungjawabkan.

Pertanggungjawaban (akuntabilitas) pemerintahan diwujudkan ke dalam LAKIP atau Laporan Akuntabilitas Kinerja Instansi Pemerintah yang merupakan laporan yang memperlihatkan bentuk pertanggungjawaban kinerja keuangan pemerintah kepada publik selama satu tahun anggaran. Setiap rupiah uang publik yang telah diberikan untuk membiayai pembangunan dan berjalannya roda pemerintahan dipertanggungjawabkan oleh pemerintah (Mursyidi, 2013). Apabila 
pemerintah daerah tidak mampu memberikan informasi mengenai kinerja pemerintah secara transparan, relevan, handal, sederhana, dan dapat dipahami oleh masyarakat sebagai konstituennya, maka akan muncul masalah akuntabilitas publik. Hal ini sesuai pendapat (Mahmudi, 2010) yang menyatakan ketidakpahaman masyarakat atas laporan kinerja yang disajikan oleh pemerintah maka akan menimbulkan permasalahan. Oleh karena itu diperlukan adanya transparansi dan penjelasan yang benar dan mudah dipahami oleh masyarakat dalam laporan keuangan yang disusun oleh pemerintah. Bentuk transparansi dalam organisasi pemerintahan adalah dengan memberikan informasi keuangan secara transparan dan benar kepada masyarakat.

Asian Develompment Bank, 2000 dalam (Kharisma, 2014) mengemukakan terdapat empat prinsip utama dalam good governance yaitu akuntabilitas, transparansi, pertanggungjawaban dan kesetaraan dan kewajaran. Akuntabilitas merupakan kejelasan fungsi, struktur, sistem dan pertanggung jawaban suatu instansi / perusahaan sehingga pengelolaan instansi atau perusahaan berjalan dan terlaksana secara efektif.

Penelitian ini sejalan dengan (Kurniawati, 2016) yang menyatakan penyajian laporan keuangan daerah berpengaruh positif terhadap transparansi dan akuntabilitas pengelolaan keuangan daerah, (Hehanussa, 2015) bahwa panyajian laporan keuangan berpengaruh positif dan signifikan terhadap transparansi dan akuntabilitas pengelolaan keuangan daerah, dmana penyajian laporan keuangan yang baik merupakan salah satu faktor untuk meningkatkan akuntabilitas pengelolaan keuangan daerah.

Berdasarkan latar belakang tersebut, maka peneliti tetarik untuk melakukan penelitian mengenai pengaruh kualitas laporan keuangan terhadap akuntabilitas kinerja Badan Pengelolaan Keuangan dan Aset Daerah Kabupaten Buton. Adapaun rumusan masalah pada penelitian ini adalah Bagaimana pengaruh kualitas laporan keuangan terhadap akuntabilitas kinerja Badan Pengelolaan Keuangan dan Aset Daerah Kabupaten Buton?. Tujuan Penelitian ini adalah untuk mengetahui pengaruh kualitas laporan keuangan terhadap akuntabilitas kinerja pada Badan Pengelolaan Keuangan dan Aset Daerah Kabupaten Buton.

\section{LANDASAN TEORI}

\section{Laporan Keuangan}

Laporan keuangan dalam akuntansi sektor publik berperan penting dalam menciptakan akuntabilitas. Laporan keuangan merupakan penyajian yang sistematis tentang posisi keuangan dan kineja suatu entitas (Hans Kartikahadi et al, 2012) Informasi akuntansi yang terutama ditujukan kepada pihak eksterrn suatu perusahaan atau organisasi disebut Laporan Keuangan (Mardiasmo, 2014).

Laporan keuangan merupakan laporan hasil (output) sedangkan masukannya (input) berupa transaksi bisnis. Supaya masuk ke dalam sistem pencatatan, maka keseluruh input harus dilengkapi dengan bukti-bukti transaksi (Toto Prihadi, 2013). Laporan keuangan yang tepat telah menjadi komponen kunci dimana akuntabilitas diharapkan dan dapat ditunjukkan. Penilaian kinerja organisasi dapat dilakukan oleh stakeholder Melalui laporan keuangan. 
Dari beberapa definisi tersebut dapat disimpulkan bahwa laporan keuangan adalah informasi kuantitatif tentang posisi keuangan secara tertulis dari suatu entitas pelaporan.

\section{Kualitas Laporan Keuangan}

Laporan keuangan sektor publik merupakan komponen penting untuk menciptakan akuntabilitas publik. Akuntansi sektor publik berperan untuk menyampaikan laporan keuangan sebagai salah satu bentuk pelaksanaan akuntabilitas publik. Untuk menciptakan akuntabilitas maka laporan keuangan yang disampaikan juga harus berkualitas.

Kualitas laporan keuangan adalah ukuran-ukuran normatif yang perlu diwujudkan dalam informasi akuntansi sehingga dapat memenuhi tujuannya (Standar Akuntansi Pemerintah, 2010) untuk kebutuhan perencanaan, pengendalian, dan pengambilan keuputusan merupakan suatu keharusan bagi pemerintah untuk memperhatikan informasi yang disajikan dalam laporan keuangan.

Infomasi laporan keuangan pemerintah harus memenuhi beberapa karakteristik kualitatif yang sebagaimana disyaratkan dalam Peraturan Pemerintah No. 71 Tahun 2010 tentang Standar Akuntansi Pemerintahan, yaitu :

1. Relevan

Laporan keuangan dikatakan relevan apabila informasi yang termuat didalamnya dapat mempengaruhi keputusan pengguna dengan membantu mereka mengevaluasi peristiwa masa lalu atau masa kini dan memprediksi masa depan serta menegaskan atau mengkoreksi hasil evaluasi mereka di masa lalu. Informasi yang relevan yakni memiliki manfaat umpan balik, memiliki manfaat prediktif, Tepat waktu, lengkap.
2. Andal

informasi dari laporan keuangan bebas dari pengertian yang menyesatkan dan kesalahan material, menyajikan setiap fakta secara jujur serta dapat diverifikasi. Informasi yang relevan, tetapi jika penyajiannya tidak dapat diandalkan maka pengguna informasi tersebut mempunyai potensi menyesatkan. Informasi dikatakan andal apabila memenuhi karakteristik sebagai berikut : Penyajian jujur, Dapat diverifikasi, Netral

3. Dapat Dibandingkan

Informasi yang disajikan dalam laporan keuangan akan lebih berguna jika dapat dibandingkan dengan laporan keuangan periode sebelumnya atau laporan keuangan entitas pelaporan lain pada umumnya. Perbandingan dapat dilakukan secara internal dan eksternal. Perbandingan secara internal dapat dilakukan bila suatu entitas menerapkan kebijakan akuntansi yang sama dari tahun ke tahun. Perbadingan secara eksternal dapat dilakukan bila entitas yang diperbandingkan menerapkan kebijakan akuntansi yang sama.

4. Dapat dipahami

Informasi yang disajikan dalam laporan keuangan dapat dipahami oleh pengguna dan dinayatakan dalam bentuk serta istilah yang disesuikan dengan batas pemahaman para pengguna. Untuk itu, pengguna diasumsikan memiliki pengetahuan yang memadai atas kegiatan dan lingkungan operasi entitas pelaporan, serta adanya kemauan pengguna untuk mempelajari informasi dimaksud.

\section{Akuntabilitas}

Akuntabilitas merupakan kewajiban agen (pemerintah) untuk mengelola sumber daya, melaporkan dan mengungkapkan segala aktivitas dan kegiatan yang berkaitan dengan penggunaan sumber daya publik kepada pemberi mandat (Mahmudi, 2010). 
Menurut (Halim dan Kusufi, 2014) akuntabiltas adalah kewajiban untuk memberikan pertanggungjawaban atau menjawab dan menerangkan kinerja dan tindakan seseorang/badan hukum atau pimpinan suatu organsasi kepada pihak yang memiliki hak atau berkewenangan untuk meminta keterangan atau pertanggung jawaban.

Akuntabilitas tidak hanya sebatas pada penyusunan laporan keuangan, tetapi juga sebagai upaya dalam pemberantasan korupsi, dan upaya untuk menguatkan akuntabilitas merupakan langkah pentingyang perlu dilakukan untuk menngkatkan kesejateraan masyarakat (Dwi Afriyanti, Harpanto Guno Sabanu, 2015). Karena akuntabilitas sangat komplek, maka perlu untuk menentukan siapa yang bertanggung jawab, kepada siapa, mengapa, dan dengan sarana apa serta mengidentifikasi jenis akuntabilitas. Walaupun sangat kompleks, namun terwujudnya akuntabilitas merupakan tujuan utama dari reformasi sektor publik (Jones dan Maurice 1996 dalam (Adi A.S, 2011).

Stewart, 1984 (H. B. Darwanis, 2016) menyatakan bahwa ada lima basis akuntabilitas sebagai standar penilaian akuntabilitas, yaitu: Akuntabilitas Hukum dan Kejujuran, Akuntabilitas Proses, Akuntabilitas Kinerja, Akuntabilitas Program dan Akuntabilitas Kebijakan.

Mardiasmo, 2009 dalam (Safkaur, Afiah, Poulus, \& Dahlan, 2019) menyatakan akuntabilitas terdiri dari dua yaitu :

1. Akuntabilitas Vertikal merupakan pertanggungjawaban atas pengelolaan dana kepada otoritas yang lebih tinggi.

Copyright (C) 2020, FINANCIAL: Jurnal Akuntansi
2. Akuntabilitas Horizontal merupakan pertanggungjawaban kepada masyarakat luas.

Akuntabilitas kinerja instansi pemerintah adalah perwujudan kewajiban suatu instansi pemerintah untuk mempertanggungjawabkan keberhasilan atau kegagalan pelaksanaan program dan kegiatan yang telah diamanatkan para pemangku kepentingan dalam rangka mencapai misi organisasi secara terukur dengan sasaran target yang telah ditetapkan melalui laporan kinerja instansi pemerintah yang disusun secara periodik.

\section{Kinerja}

(Moeheriono, 2014) kinerja adalah gambaran mengenai tingkat pencapaian pelaksanaan suatu program kegiatan atau kebijakan dalam mewujudkan sasaran, tujuan, visi dan misi organisasi yang dituangkan melalui perencanaan strategis suatu organisasi. (Mangkunegara, 2017) kinerja merupakan hasil kerja secara kualitas yang dicapai dalam meelaksanakan tugas sesuai dengan tanggung jawab yang dberikan.

Indikator kinerja menurut (Mahmudi, 2013)adalah ukuran kuantitatif atau kualitatif yang menggambarkan tingkat pencapaian suatu sasaran atau tujuan yang telah ditetapkan.

\section{METODE}

Jenis penelitian ini adalah deskriptif. Data penelitian berupa data primer. Instrument penelitian berupa kuisioner. Populasi penelitian adalah seluruh pegawai Badan Pengelolaan Keuangan dan Aset Daerah Kabupaten Buton. Sampel penellitian berjumlah 35 orang. Teknk pengambilan sampel adalah non probability sampling dengan metode 
sensus, yaitu metode pengambilan sampel dimana seluruh populasi dijadikan sebagai sampel (Sugiyono, 2015). Data penelitian dianalisis menggunakan model regresi sederhana yang didahului oleh uji prasyarat berupa uji linearitas dan normalitas. Persamaan regresi sederhana dalam penelitian ini adalah :

$$
\mathrm{Y}=\alpha+\beta \mathrm{X}+\varepsilon
$$

Dimana:

$$
\begin{aligned}
\mathrm{Y}= & \text { Akuntabilitas Kinerja Instansi } \\
= & \text { Pemerintah } \\
\alpha= & \text { Konstanta } \\
\beta= & \text { Koefisisen Regresi } \\
\mathrm{X}= & \text { Kualitas Laporan Keuangan } \\
\mathrm{E} & \text { Error }
\end{aligned}
$$

\begin{tabular}{|c|c|c|c|c|}
\hline \multirow{3}{*}{$\begin{array}{c}\text { Item } \\
\text { Pernyataan }\end{array}$} & \multicolumn{4}{|c|}{ Variabel } \\
\hline & \multicolumn{2}{|c|}{$\begin{array}{c}\text { Kualitas Laporan } \\
\text { Keuangan }\end{array}$} & \multicolumn{2}{|c|}{ Akuntabiltas Kinerja } \\
\hline & $\mathrm{R}$ & $\begin{array}{c}\text { Alpa } \\
\text { croncbach }\end{array}$ & $\mathrm{R}$ & $\begin{array}{c}\text { Alpa } \\
\text { croncbach }\end{array}$ \\
\hline 1 & 711 & \multirow{10}{*}{0,858} & 911 & \multirow{10}{*}{0,876} \\
\hline 2 & 745 & & 908 & \\
\hline 3 & 726 & & 682 & \\
\hline 4 & 457 & & 476 & \\
\hline 5 & 722 & & 602 & \\
\hline 6 & 860 & & 704 & \\
\hline 7 & 532 & & 746 & \\
\hline 8 & 725 & & 754 & \\
\hline 9 & 463 & & 390 & \\
\hline 10 & 654 & & 726 & \\
\hline
\end{tabular}

Hipotesis penelitian ini adalah :

$$
\begin{aligned}
\mathrm{H}_{0}: \mu=0 & \text { Tidak ada pengaruh kualitas } \\
& \text { laporan keuangan terhadap } \\
& \text { akuntabilitas kinerja pada } \\
& \text { Badan } \\
& \text { Keuangan dan Aset Daerah }
\end{aligned}
$$

Tabel 1

Rekapitulasi Nilai Validitas Dan Reliabilitas Instrumen

Sumber : Data primer diolah,2020

Syarat minimum untuk dianggap valid apabila $r \geq 0,3$. Jika koefisien korelasi kurang dari 0,3, maka butir instrument tersebut dinyatakan tidak valid. Untuk reabilitas instrumen didasarkan pada
Kabupaten Buton

$$
\begin{aligned}
\mathrm{H}_{1}: \mu \neq \quad & \text { Ada pengaruh kualitas } \\
& \text { laporan keuangan terhadap } \\
\text { akuntabilitas kinerja pada } & \\
\text { Badan Pengelolaan } & \text { Keuangan dan Aset Daerah } \\
& \text { Kabupaten Buton }
\end{aligned}
$$

\section{HASIL DAN PEMBAHASAN Validitas dan Reliabilitas Instrumen}

Kuisioner yang digunakan pada penelitian ini melalui tahapan validitas dan relabilitas. Uji validitas merupakan suatu derajat ketepatan alat ukur penelitian tentang isi atau arti sebenarnya yang diukur. Uji reliabilitas adalah uji derajat ketepatan, ketelitian, keakuratan yang ditunjukkan oleh instrument pengukuran. Hasil uji validitas dan reliabilitas intrumen penelitiaan dapat dilihat pada tabel 1 . 
Berdasarkan tabel 1 diketahui bahwa untuk keseluruhan item pernyataan 1 - 10 mengenai kualitas laporan keuangan dan akuntabilitas kinerja memiliki nilai $\mathrm{r} \geq$ 0,3 dan nilai reliabilitas keduanya $>0,7$ sehingga dapat disimpulkan bahwa instrumen yang digunakan pada penelitian ini valid dan relabel.

\section{Uji Linearitas dan Normalitas}

Setelah melakukan uji validitas dan reliabilitas, maka selanjutnya dilakukan uji linearitas dan normalitas terhadap data penelitian. Hasil uji linearitas dan normalitas data dapat dilihat pada tabel 2.

Tabel. 2

\begin{tabular}{|c|c|c|c|c|}
\hline \multirow[t]{2}{*}{ Variabel } & \multicolumn{2}{|c|}{$\begin{array}{c}\text { Linearitas } \\
\text { (Deviation from } \\
\text { linearity) }\end{array}$} & \multicolumn{2}{|c|}{ Normalitas } \\
\hline & Sig. & $\mathrm{A}$ & Sig. & $\alpha$ \\
\hline $\begin{array}{l}\text { Kualitas Laporan Keuangan } \\
\text { Akuntabilitas Kinerja }\end{array}$ & 0,076 & 0,05 & $\begin{array}{l}0,082 \\
0,313\end{array}$ & 0,05 \\
\hline
\end{tabular}

Sumber : Data PrimerDiolah 2020

Berdasarkan tabel 2 diketahui bahwa nilai signifikansi (Deviation from linearity) yang diperoleh sebesar $0,07>\alpha$ sama dengan 0,05, maka dapat disimpulkan bahwa antara variabel kualitas laporan keuangan dengan akuntabilitas kinerja instansi pemerintah memiliki hubungan linear secara signifikan.

Selanjutnya dari hasil uji normalitas diketahui bahwa nilai signifikansi yang diperoleh untuk data kualitas laporan keuangan sebesar 0,082 dan untuk data akuntabilitas kinerja diperoleh nilai signifikansi sebesar 0,313. Oleh karena nilai signikansi dari kedua data yang diperoleh $>\alpha$ sama dengan 0,05 maka dapat dsimpulkan bahwa data pada penelitian ini berdistribusi normal.

Karena data pada penelitian memenuhi syarat lnearitas dan normalitas, maka selanjutnya dilakukan uji regresi sederhana untuk mengetahui pengaruh kualitas laporan keuangan terhadap Copyright (C) 2020, FINANCIAL: Jurnal Akuntansi akuntabilitas kinerja pada BPKAD Kabupaten Buton.

\section{Uji Hipotesis Penelitian}

Berdasarkan hasil uji prasyarat yang dilakukan diketahui bahwa data pada penelitian ini memenuhi syarat linearitas dan normalitas, maka selanjutnya dilakukan uji regresi sederhana untuk mengetahui pengaruh kualitas laporan keuangan terhadap akuntabilitas kinerja pada Badan Pengelolaan Keuangan dan Aset Daerah Kabupaten Buton.

Pengambilan keputusan didasarkan pada nilai signifikansi. Jika nilai signifikansi yang diperoleh $<\alpha$ sama dengan 0,05 maka kesimpulan $\mathrm{H}_{1}$ diterima dan $\mathrm{H}_{0}$ ditolak dan sebaliknya jika nilai signifikansi yang diperoleh $>\alpha$ sama dengan 0,05 maka kesimpulan $\mathrm{H}_{0}$ diterima dan $\mathrm{H}_{1}$ ditolak. Hasil uji hipotesis statistik penelitian dapat dilihat pada tabel 3 dibawah ini: 


\section{Tabel 3}

Hasil Uji Pengaruh Kualitas Laporan Keuangan Terhadap Akuntabilitas Kinerja

\begin{tabular}{|c|c|c|c|c|c|c|}
\hline & Model & $\mathrm{R}$ & $\begin{array}{c}\text { R Square } \\
\left(\mathrm{R}^{2}\right)\end{array}$ & $\begin{array}{c}\text { Adjusted } \\
\text { R } \\
\text { Square }\end{array}$ & $\begin{array}{c}\begin{array}{c}\text { Unstandarized } \\
\text { Coeficient }\end{array} \\
\text { B }\end{array}$ & Sig \\
\hline 1 & $\begin{array}{l}\text { Regression } \\
\text { Constan } \\
\mathrm{X}\end{array}$ & $.968^{\mathrm{a}}$ & 0,938 & .936 & $\begin{array}{l}.341 \\
.999\end{array}$ & 0,000 \\
\hline
\end{tabular}

Sumber : Data primer diolah,2020

Berdasarkan tabel 3 diketahui bahwa nilai korelasi hubungan $(\mathrm{R})$ yaitu sebesar 0,968. Dari hasil output tersebut diperoleh koefisien determinasi $\left(\mathrm{R}^{2}\right)$ sebesar 0,938 yang berarti bahwa pengaruh kualitas laporan keuangan terhadap varabel terkat akuntablitas kikerja sebesar 93\%. Jika nilai pada tabel 3 dimasukkan dalam persamaan regersi maka diperoleh :

$$
\mathrm{Y}=0,341+0,999 \mathrm{X}
$$

Dari persamaan tersebut diketahui nilai konstanta sebesar 0,341 artinya jika kualitas laporan keuangan konstan maka akuntabilitas kinerja instansi pemerintah adalah sebesar 0,341 Koefisien Regresi kualitas laporan keuangan sebesar 0,999 menyatakan bahwa setiap 1 kenaikan kualitas laporan keuangan maka akuntabilitas kinerja Badan Pengelolaan Keuangan dan Aset Daerah Kabupaten Buton akan meningkat sebesar 0,999.

Untuk nilai R (korelasi) kualitas laporan keuangan dan akuntabilitas kinerja yang diperoleh sebesar 0,968, dan untuk nilai koefisien determinasi $\left(\mathrm{R}^{2} / \mathrm{R}\right.$ Square $)$ diperoleh nilai sebesar 0,938 yang berarti bahwa pengaruh kualitas laporan keuangan terhadap akuntablitas kinerja Badan Pengelolaan Keuangan dan Aset Daerah Kabupaten Buton sebesar 93,8\% dan $6,4 \%$ sisanya dipengaruhi oleh faktorfaktor lain.

Hasil uji regresi sederhana diperoleh nilai siginifikansi sebesar $0,000<\alpha$ sama dengan 0,05 maka dapat disimpulkan bahwa $\mathrm{H}_{1}$ diterima dan $\mathrm{H}_{0}$ ditolak. Hal ini berarti bahwa kualitas laporan keuangan berpengaruh positif dan signifikan terhadap akuntabilitas kinerja Badan Badan Pengelolaan Keuangan dan Aset Daerah Kabupaten Buton.

Hasil tersebut sejalan dengan hasil penelitian (Sakti \& Masitoh, 2018) bahwa laporan keuangan memberikan pengaruh terhadap kinerja pegawai, (Silalahi \& Sinambela, 2017) bahwa kualitas laporan keuangan berpengaruh signifikan terhadap laporan akuntabilitas pemerintah Sumatera Utara. Hal ini berarti bahwa semakin meningkatknya kualitas laporan keuangan maka akan semakin menunjukkan tingkat akuntabilitas kinerja dari instansi pemerintahan. Dengan kata lain, akuntabilitas kinerja dapat diukur dari kualitas laporan keuangan yang dihasilkan. Hal ini sejalan pula dengan (Basri \& Nabiha, 2014) bahwa laporan keuangan yang tepat telah menjadi komponen kunci dimana akuntabilitas dapat ditunjukkan, dan melalui laporan keuangan stakeholders dapat melakukan penilaian terhadap kinerja suatu instansi/organisasi.

Hasil penelitian ini menunjukkan bahwa penyajian laporan keuangan yang berkualitas mendorong terciptanya akuntabilitas kinerja instansi dan merupakan syarat terciptanya pelaksanaan pemerintahan yang baik. Berdasarkan PP 
No. 71 Tahun 2010 laporan keuangan pemerintah dapat dikatakan berkualitas apabila memenuhi unsur-unsur relevan, andal, dapat dibandingkan dan dapat dipahami. Laporan keuangan daerah akan mendapatkan opini Wajar Tanpa Pengecualian (WTP) dari Badan Pemeriksa Keuangan (BPK), jika laporan keuangan tersebut mendapatkan opini selain WTP maka dapat dikatakan kualitas dari laporan keuangan masih belum maksimal dikarenakan belum menerapkan standar akuntansi pemerintah (SAP) dengan baik dan benar. Jika standar akuntansi pemerintahan diterapkan dengan baik maka akan berdampak pada peningkatan kualitas laporan keuangan pemerintah.

Laporan keuangan yang menjadi dasar dalam pengukuran akuntabilitas kinerja suatu instansi hendaknya dapat memberikan informasi yang akurat dan jelas sebagai bentuk pertanggng jawaban. Laporan keuangan harus dapat menunjukkan informasi tentang kinerja dan akuntabilitas kinerja instansi pemerintah yang dibutuhkan karena laporan keuangan sangat dibutuhkan oleh pemerintah dalam mengambil keputusan guna melakukan perbaikan-perbaikan manajemen dalam penyelenggaraan urusan pemerintahan agar lebih baik dan maksimal (Pratiwi \& Setyowati, 2017). Hal ini sejalan dengan yang dikemukakan oleh (Safkaur et al., 2019) bahwa laporan keuangan merupakan alat pertanggungjawaban utama pemerintah kepada masyarakat umum juga parlemen harus memberikan informasi yang jelas sebagai bentuk representasi dari kinerja yang dilakukan.

\section{KESIMPULAN DAN SARAN Kesimpulan}

Copyright (C) 2020, FINANCIAL: Jurnal Akuntansi
Dari hasil penelitian dan pembahasan yang dilakukan kesimpulan penelitian ini adalah kualitas laporan keuangan berpengaruh positif dan signifikan terhadap akuntabilitas kinerja Badan Pengelolaan Keuangan dan Aset Daerah Kabupaten Buton. Artinya bahwa baik tidaknya kualitas laporan keuangan yang dihasilkan akan menunjukkan baik tidaknya pula akuntabilitas kinerja dari suatu instansi pemerintah. Akuntabilitas kinerja instansi pemerintah yang menyajikan laporan keuangan sesuai Standar Akuntansi pemerintahan akan menghasilkan laporan keuangan yang berkualitas.

\section{Saran}

Hasil penelitian ini diharapkan dapat dijadikan sebagai acuan untuk melakukan penelitian lanjutan yang tidak hanya berfokus pada kualitas laporan keuangan dan akuntabilitas kinerja tetapi dapat pula dikembangkan ke variabel lain yang belum diteliti.

\section{DAFTAR PUSTAKA}

Adi A.S. (2011). Laporan Keuangan Pemerintah Daerah: Mengerek Responsi dan Partisipasi Masyarakat Sebagai Suatu Keniscayaan. Jurnal Akuntansi Dan Auditing, 7(2), 134146.https://doi.org/10.14710/jaa.v7i2. 4682

Basri, H., \& Nabiha, A. K. S. (2014). Accountability of Local Goverment : The Case of Aceh Province, Indonesia. 3(December), 1-14.

Darwanis, H. B. (2016). Analisis Akuntabilitas Keuangan pada Kantor Kementerian Agama Dalam Wilayah Provinsi Aceh. 9(2), 105-110.

Darwanis, S. C. (2013). Akuntabilitas Kinerja Instansi Pemerintah. Jurnal Telaah Dan Riset Akuntansi, 6(2), 150-174.

Dwi Afriyanti, Harpanto Guno Sabanu, 
dan F. N. (2015). Penilaian indeks akuntabilitas instansi pemerintah. 2142.

Halim dan Kusufi. (2014). Teori, Konsep dan Aplikasi Akuntansi Sektor Publik. Jakarta: Salemba Empat.

Hans Kartikahadi et al. (2012). Akuntansi keuangan berdasarkan SAK berbasis IFRS Buku 1. Jakarta: Salemba Empat.

Hehanussa, S. J. (2015). Pengaruh Penyajian Laporan Keuangan Daerah dan Aksesibilitas Laporan Keuangan Daerah Terhadap Transparansi dan Akuntabilitas Pengelolaan Keuangan Daerah Kota Ambon. Conference in Busniess, Accounting and Management, 2, 82-90.

husaini, lucy aditya, L. (2013). Analisis Pengaruh Akuntabilitas Dan Transparansi Pengelolaan Keuangan Daerah Terhadap Kinerja Pemerintah Daerah. Akuntansi Dan Manajemen, Volume 3,(1), 21-41.

Kharisma, B. (2014). Good Governance Sebagai Suatu Konsep Dan Mengapa Penting Dalam Sektor Publik Dan Swasta (Suatu Pendekatan Ekonomi Kelembagaan). Jurnal Buletin Studi Ekonomi, 19(1), 9-30.

Kurniawati, M. M. H. (2016). Pengaruh Penyajian Laporan Keuangan Daerah , Aksesibilitas Laporan Keuangan Daerah , dan Sistem Akuntansi Keuangan Daerah Terhadap Transparansi dan Akuntabilitas Pengelolaan Keuangan Daerah ( Studi pada Satuan Kerja Perangkat Daerah Kabupaten Jember ) The.

Mahmudi. (2010). Manajemen Keuangan Daerah. Jakarta: Erlangga.

Mahmudi. (2013). Manajemen Kinerja Sektor Publik. Yogyakarta: UPP STIE YKPN.

Mangkunegara, A. (2017). Evaluasi Kinerja SDM. Jawa Barat: REFIKA ADITAMA.

Mardiasmo. (2014). Akuntansi Keuangan Dasar 1. Yogyakarta: BPFE.
Moeheriono. (2014). Pengukuran kinerja berbasis kompetensi (Edisi Revisi). Jakarta: Raja Grafindo Persada.

Mursyidi. (2013). Akuntansi Pemerintahan di Indonesia. Bandung: Refika Editama.

Pratiwi, R. D., \& Setyowati, L. (2017). Determinan yang Mempengaruhi Akuntabilitas kinerja Pemerintah Kota Semarang. Jurnal Bisnis Dan Ekonomi (JBE), 24(1), 94-102.

Safkaur, O., Afiah, N. N., Poulus, S., \& Dahlan, M. (2019). the Effect of Quality Financial Reporting on Good Governance. International Journal of Economics and Financial Issues, 9(3), 277-286. https://doi.org/10.32479/ijefi.8047

Sakti, F., \& Masitoh, S. (2018). Akuntabilitas Kinerja Pada Dinas Pendidikan. 8(2), 156-170. Retrieved from

file:///C:/Users/ACER/Downloads/37 49-9772-1-SM.pdf

Silalahi, T., \& Sinambela, S. (2017). Determinants of Financial Report Accountability, and It'S Implication on Financial Report Quality an Empirical Study of Financial Report Statement in North Sumatra Province, Indonesia. International Journal of Economics, Commerce and Management United Kingdom, 3(3), 159-172. Retrieved from http://ijecm.co.uk/

Standar Akuntansi Pemerintah. (2010). Peraturan Pemerintah (PP) tentang Standar Akuntansi Pemerintahan (p. 11). p. 11. Retrieved from https://peraturan.bpk.go.id/Home/Det ails/5095/pp-no-71-tahun-2010

Sugiyono. (2015). Metode Penelitian Kombinasi (Mixed Method). Bandung: Alfabeta.

Toto Prihadi. (2013). Analisis laporan keuangan: teori dan aplikasi. Jakarta: PPM.

www.dpr.go.id. (2004). Undang-Undang No 32 Tahun 2004 Tentang Pemerintah Daerah. Dpr, 249. 
FINANCIAL: Jurnal Akuntansi, Volume 6 Nomor 1, Juni 2020

Retrieved from http://www.dpr.go.id/dokjdih/docume nt/uu/33.pdf

\section{PROFIL SINGKAT}

Nining Asniar Ridzal, Lahir di Kendari Propinsi Sulawesi Tenggara pada Tanggal 25 Maret 1984. Pendidikan Terakhir Pascasarjana Program Studi Ilmu Ekonomi Konsentrasi Akuntansi dari Universitas Halu Oleo Kendari, lulus tahun 2016. Saat ini sebagai Dosen tetap Program Studi Akuntansi Universitas Muhammadiyah Buton. 